\title{
The Formation of the Atypical Lithuanian Family Between the Second Half of the 19th and the Beginning of the 20th Centuries.
}

\section{Dalia MARCINKEVIČIENE்}

In Lithuanian scholarship the family has attracted the attention only of ethnographers. The latter characterize it in a few concepts: the patriarchal, the extended, and the nuclear family. These concepts define the general structure of the family but do not describe all its possible relationships. The culturological aspects of the family studies have not been discussed in the context of Lithuanian history as yet. Meanwhile, in Western studies with the help of the works of P. Ariés, D.Markowska", the authors of the magazine "History of Family", themes concerning the family, family relations, the rearing of the young and childhood are not only very popular, but also have even become the subject of interdisciplinary studies.

In this article I shall explore the formation of the atypical Lithuanian family from the second half of the nineteenth to the beginning of the twentieth centuries. It is not easy to define the boundary between the traditional and the atypical Lithuanian family, because the traditional family is not clearly defined in the history of Lithuanian culture. In some essays a particular image of the Lithuanian family has been formed: diligent and moral parents, irreproachable relationships, exceptional honour paid to the mother and women, modest and good-tempered daughters. This is more likely a stereotypical than a real view. Literature and periodicals from the end of the 19th century show the opposite. In the pages of "Aušra" and "Varpas" - the first Lithuanian social, political and cultural monthly magazines in Lithuania (published in 1883-1905). Lithuanian male intellectuals depicted Lithuanian women as uneducated, cold and superstitious. According to the Lithuanian man of letters, Jonas MačysKèkštas (1867-1902) only in the romantic imagination of some Lithuanians, do there exist girls who are apple-cheeked, blue-eyed, and ready to bring up Lithuanians for Lithuania ${ }^{2}$. As the question of the traditional Lithuanian family is still open for discussions and there is no factographical study of the history of the family, it may be useful to describe what the traditional Lithuanian family is not. For this rea-

${ }^{1}$ P. Ariés, Centuries of Childhood, New York, 1972; D. Markowska, Rodzina wiejska na Podlasiu: 1864-1964,Warszawa, 1970.

${ }^{2}$ J.M. Kèkštas, Draugija pavojuje, Varpas, 1, 1893, 1-2. 
son I have chosen to examine divorce cases among the Catholic population. They reflect not only the various family relationships, but also the factors, which gave rise to them.

The great amount of available documentation led me to seek a method, which would allow the subject not to become buried by the data and permit its analysis according to various tendencies of the cultural phenomenon. I have chosen the social-cultural-statistical method. Similar research methods are popular among American, Western European and Russian historians, who are interested in the family problems, such as J. Hajnal, D. Kingsley, P. Ilina ${ }^{3}$.

First we must outline the legal aspect of the topic and examine the statistics of divorce among the Catholic population.

The legal aspect of divorce among the Catholic population was established by the Civil Code of Tsarist Russia, i.e. by the first part of the 10th volume of The Summary of Law and the Marriage Law of 1863, which was influenced by the Canon Law ${ }^{4}$. This law provided the religious way of divorce. Thus the legal right to divorce among the Catholic population which made up $83 \%$ of the Kaunas gubernia, the biggest part of Lithuania, was confirmed only in the Consistory Court of the Bishopric of Žemaitija. According to the Codex of the Canon Law of the Catholic Church it was impossible to abolish a legally-contracted marriage. Only the death of one of the spouses could dissolve the sacramental tie of marriage. The only way of entirely lawful divorce, which was sanctioned by the jurisdiction of the Church, was to recognise a marriage as invalid, i.e. to nullify $\mathrm{it}^{5}$.

According to the Canon Law, marriage could be dissolved by the separation (so-called "separation for a table and bed" $)$ granted in the Church's Courts. This divorce de facto differed from civil divorce, because it was granted for a limited period of time with the opportunity to renew the marriage. The couple being in the separation had no right to re-marry ${ }^{7}$. Cases of separations were investigated after the bishop received a plea claiming one of the couple was guilty of adultery, violent behaviour or constraining.

The Canon Law of the Catholic Church speaks about the limited possibilities of the divorce. Nevertheless, we can only tell whether divorce was really a rare measure, which regulated the family relationship in the Lithuanian society from the second half of the 19th to the beginning of the 20th centuries, if we have statistical data relevant to this process. It is not very easy. Divorces among the Catholic population were not specified in the statistics records of the Tsarist government. Its general outline was reconstructed from documents issued by

${ }^{3}$ D. Kingsley, Marital dissolution in the United States, Washington, 1973; J. Hajnal, European marriage patterns in perspective, London, 1965; I.P. Ilina, Vlijanie voin na brachnost' sovetskikh zhenshchin, Brachnost', rozhdaemost'v Rossii i v SSSR, Moccow, 50-61.

${ }^{4} Z$ Zakony o razvode pravoslavnogo i nepravoslavnogo ispovedanija, Moccow, 1909, 258.

${ }^{5}$ Ibid.

'Ibid., 259.

${ }^{7}$ Ibid., 167-168. 
the Consistory of the Bishopric of Žemaitija between 1863 and 1904. This time path has been chosen in a formal way. While reseaching the internal processes of social life, such as family relations, it is not correct to use the periodisation of the national rebirth. 278 Catholic applications for divorce, 132 of which were granted ${ }^{8}$, are preserved in the records of the bishopric, held in the LVIA. By comparing Catholic marriages during the same period, which in the Kaunas gubernia averaged 8.763 per annum ${ }^{9}$, one could estimate the Catholic divorce rate at 0.1 divorces per 1000 marriages. So the statistics confirm the rare occurrence of official divorces in the larger part of Lithuania, and at the same time they raise some questions. What determined the small number of the official divorces: little interest in society or the Canon Law itself? The first case could prove an argument about the moral strength of the Lithuanian family and the unbreakable nature of the marriage. However, it is difficult to explain why Catholics registered many illegitimate children. Obviously, one possible hypothesis is that the rare occurrence of official divorces was determined by the Russian Civil Law, Canon Law and its interpretation by the Consistory Court of the bishopric of Žemaitija, all of which regulated the divorce. The real need for divorce, I think, was much greater and did not correspond with the official statistics. The limited possibilities of gaining a legal divorce created alternatives to legal divorce and conditioned the emergence of atypical families in society: 1 . changing faith, 2. emigration, 3. "illegal family", which consisted of a couple illegally divorced and re-married without the Church's blessing, and 4. "compulsory family", which was lawful de jure, but dissolved de facto.

In Lithuanian society during the second half of the 19th and the beginning of the 20th centuries, as well as in Lithuania between World Wars or during the Soviet period, there were, apart from psychological-emotional motives, objective social reasons, which settled the existence of the atypical, i.e. "illegal" and "compulsory" families. During different historical periods these social reasons were not the same. In the second half of the 19th and the beginning of the 20th centuries the atypical family was forming as an alternative to the official, legal regulations of the marriage. It is obvious in the practice of the Church Court.

\section{Divorce possibilities in the Church Court}

In this essay, the regulations of the Canon Law, which deal with divorce are not exhaustively discussed. The present concern is to ascertain the real possibilities available in the Church Court of Žemaitija to cancel a marriage or to obtain a separation. Case analysis suggests that these depended on the canons, which were interpreted in the context of Russian Civil Law, in the Church Court, as well as

${ }^{8}$ Data about Catholic divorces in 1863-1904 collected from LVIA, f.669, ap.4.

${ }^{9}$ Data about Catholic marriages in 1863-1904 collected from Pamiatnaia knizhka Kovenskoj gubernii 
according to the information provided by the parish priest concerning details of discordant married life. It caused not only the results of the cases, but it formed the prejudiced behaviour of Catholics after the dissolution of the family: to appeal to the Church Court or to find the alternative ways to solve their family relationship problems.

The Church Court could nullify a union, if there was a violation of absolute or relative conditions of the marriage. Absolute conditions meant: marriage of a Catholic to a non-Christian; the contracting of a new marriage while the old one was still legally valid, entering an abbey or consecration to the priesthood, spiritual or actual infidelity of the spouses ${ }^{10}$. After violation of the absolute conditions of the marriage the spouses themselves, and also every person who informed about the violation could institute the proceedings to nullify the union $^{11}$. The latter cases were mostly inspired by clergy. Relative conditions of the marriage were: the age qualification (18 years for men, 16 for women), impotence, marriage against free-will ${ }^{12}$. These cases could be brought in an action by the consorts themselves or by their $\mathrm{kin}^{13}$. However, because of the additional restrictions in the standards of the Canon Law, cases concerning violation of the conditions of the marriage often were not a basis to nullify the marriage. For example, a plaintiff who sought legal divorce on the grounds of impotence had to prove in the Court that the defendant had physical weakness before the marriage, otherwise the plaintiff had to content herself with a separation only. A marriage contracted against free-will could be nullified, if the physical and mental state of the plaintiff prevented him from acting consciously during the legalization of the union. Maybe for this reason, this ground for nullification was used rarely. During 41 years the Consistory of the Bishopric of the Kaunas gubernia received 89 applications for nullification ${ }^{14}$. Even more rarely did such cases receive an affirmative judgement. Of the aforementioned 89 applications, 77 decisions were negative ${ }^{15}$. On the other hand, recognition of a marriage as illegal led to financial penalties. After nullification, the couple was fined between 6 and 270 rubbles in favour of the Court ${ }^{16}$. Impotence of the spouse was the most common cause for nullifying a marriage, as a result of the violations of the relative conditions. In such a cases a plaintiff required a complete legal divorce. The applications to nullify a union on the grounds of impotence could be brought not earlier than 3 years after the wedding. Childless marriage was not a decisive reason for nullification, neither was the voluntary confession of a plaintiff or defendant about their physical weakness. For ex-

${ }^{10} \mathrm{~J}$. Sideravičius, Teisinis santuokos reguliavimas buržuazinèje Lietuvoje, $L M A D A$, 1(70), $1980,47$.

${ }^{11}$ Ibid.

${ }^{12}$ Ibid.

${ }^{13}$ Ibid.

${ }^{14}$ Data selected from: LVIA, f. 669, ap. 4.

${ }^{15}$ Ibid.

${ }^{16}$ Zakony..., 167. 
ample, Marija Karšauskienè applied to the Consistory asking to nullify her marriage because of the impotence of her husband. After 3 years, in 1887, the Church Court's judgement in this case was unfavourable and the couple were forced to live together. After 3 more years both Karšauskases applied to the Consistory again. In his application for divorce, the husband confessed that he had been unable to live sexually with his wife and had no claims on her. The Karšauskases sent similar applications to the Consistory for several years but there was no decree. In 1893, after 9 years after the first application and after 13 years of married life , Karšauskienè appealed to the Church Court once more. She wrote: "The Court obliged me to live with my husband, though God be thanked, I have lived with him already for 13 years and have even become a sick woman from such a life" ${ }^{17}$. The Court did not nullify the Karšauskases' marriage.

A medical certificate could be a weighty proof of impotence. The certificate itself and related treatments cost a plaintiff up to 25 roubles ${ }^{18}$. However, in the practice of the Courts, medical opinion did not always settle the recognition of the marriage as invalid. For example, in 1896 Juozas Litvinas produced a copy of a medical examination signed by 8 doctors. It said that his wife Alexandra had no uterus and ovary and asked to nullify his marriage. However the clergy of the Consistory in their decree stated that according to the Canon Law, marriage is ordained not only to perpetuate the family but also to satisfy the passions of body. Since Litviniené was unable to bear a child, but she could have sex, the marriage of Litvinases was recognised legal. Sixteen years later, Litvinas applied to the Consistory of the Catholic archibishopric of Mogilev, the metropolitanate to which Žemaitija belonged, asking it to nullify the marriage, but the application was rejected here too ${ }^{19}$. Even in cases where the Church Court granted a divorce, the Church itself often influenced the further life of the Catholics. The decrees indicated whether it was possible or not for the divorced couple to re-marry and specified required conditions. When the marriage of 26 years old Elena and the 56 years old doctor, Kazimieras Skudauskas, was nullified on the grounds of his impotence, the Church Court allowed Kazimieras Skudauskas to marry once more, but "only a widow, not in first youth and by no means a maiden, no matter what age she would be" 20 .

The nullifying of the marriage due to the violation of its absolute conditions had a paradoxical effect in the Court practice, and in effect it was aimed against the will of the spouses. It was meaningless to apply to the Consistory in order to legitimate the new marriage, while the old one was still valid. The Church Court usually nullified not the previous marriage, but the new one, i.e. the one, which the

\footnotetext{
${ }^{17}$ The Karšauskas divorce case (peasants), 1884, LVIA, f. 669, ap. 4, b. 1894, 1. 62.

${ }^{18}$ The Stankūnas divorce case (peasants), 1897, ibid., b. 3234, 1.48.

${ }^{19}$ The Litvinas divorce case, 1896 , ibid., b. 3128.

${ }^{20}$ The Skudauskas divorce case (nobility), 1902, ibid., b. 3861, 1. 259.
} 
plaintiff was trying to legitimate. For example, former prisoners or economic migrants, who had stayed in Russia, applied to the Žemaitijan Consistory for the recognition of their previous marriage as invalid. Separated for a long time and often forced to re-marry they usually asked to annul the previous marriage in order to legitimate a new one. For the same reason wives (or husbands) who had remained in Lithuania applied to the Consistory too. Sometimes the marital status of both spouses had been changed, so the application had to be signed by both of them. In 1894 a nobleman from Kazan, Pikelis, wrote to the Žemaitijan Consistory, that he had left Lithuania 28 years before and wanted to marry again, so he needed the annulment of the old marriage, otherwise, according to his words, it would not be possible to legitimise his son who was born in Russia ${ }^{21}$. The applications of these plaintiffs were not granted. The decrees of the Church Court indicated that neither separation of the consorts for a long time, nor adultery, nor a new family with children born in it, formed a legal basis for nullifying the previous marriage ${ }^{22}$.

The right to apply to the Consistory Court as a result of the violation of the absolute conditions of the union, as I have mentioned, was enjoyed by every one, including priests. The latter were entitled to declare the marriages of their parishioners illegal and invalid without the application of the spouses themselves. Often the decrees in such cases were devastating to the family, which sometimes even brought up children. If the marriage was recognized invalid, the family had to separate voluntarily or with the help of police and their children were declared illegitimate. Through the mediation of Jucevičius, the dean of Smilgiai parish, an action was brought against Elena and Juozas Škys. Before the marriage, the husband, had lived illegally with the sister-in-law of his future wife and had had a son. After the Šukys marriage, the former partner appealed to the dean, asking to abolish the marriage on grounds of illegality. The dean, referring to the case, declared the marriage of Šukys to be incest. In 1896 the Consistory Court confirmed the charge, declared the marriage of Škys invalid and ordered the police: "to prevent Elena and Juozas Šukys from living together immediately", and forbade them "to live even near each other, especially in the same house". The Šukyses' daughter was declared illegitimate ${ }^{23}$. The privilege of strangers and priests to examine the violations of other people's marriages did not solve the problems of the family relationship. Often these problems became more complicated and the fates of people more tragic, especially in canonical cases concerning new marriages, contracted while a previous one was still valid. After the discovery of bigamy by the Church Court, the case was tried by the Civil Court ${ }^{24}$. The latter could sentence to jail. For ex-

${ }^{21}$ The Pikelis divorce case (nobleman), 1894, ibid., b. 284, 1. 1.

${ }^{22}$ Zakony..., 139.

${ }^{23}$ Illegal marriage of Šukys family, 1894, LVIA, f. 669, ap. 4, b.2874, 1. 47.

${ }^{24}$ Zakony..., 144. 
ample, a peasant, Marija Šumanienè, wrote in her application to the Consistory: "According to the decision of Vilnius Court, due to my contracting a new marriage while the previous one was still legally valid, I was shut in a prison for a one year. I have confessed my sins and served a term of imprisonment with my young children, of whom two died in jail. I am abandoned to my own fate now. I have returned to the house of my previous (first) husband, Kazlauskas, but I have been turned out into the street together with my children. I can not return to my second husband because he is bound by no legal right, and so I do not know to which of my husbands do I legally belong now (...). I beg the Court for a passport, so now I may start working and feed my poor children"25. This woman, pushed into an anomalous situation by the Court itself, consented to become the wife of a husband chosen by the Consistory, and asked at least for a chance for herself and her children to live. The Church did not annul her first marriage and granted no separation ${ }^{26}$. Thus the nullification of a union because of the violation of its absolute conditions obviously was more useful to other interested parties than to the couple themselves.

More often Lithuanians from Kaunas gubernia used their right for a separation, which was granted by the Court because of adultery, cruel behaviour or imprisonment of the spouse. However, the separations were restricted too. For example, to give reasons for the separation on the grounds of cruel behaviour was possible only by proving the fact that the violence committed was truly dangerous to life and health. A plaintiff who sought separation because of adultery had to prove in the Church Court that his partner had really had sex with a third party. The testimony of eyewitnesses played the main role in such cases. Separations were granted with a time-limit and its end was provided by the Church Court too. Between 1863 and 1904 the Consistory was applied to for a separation 161 times. 120 applications of the plaintiffs were granted $^{27}$. The absolute majority of applicants were women, and this was not easy for them. The Canon Law instructed that children of those parents, who sought a separation, had to live with their father during the investigation of the case ${ }^{28}$. Of course, they stayed with mothers in most of the cases, because fathers usually had no pretensions to take care of the children. From their broken marriage, female plaintiffs sought, together with the separation, the only official guarantee of their freedom - a separate passport. After marriage this was given by the civil authorities only to the husband. Therefore, a wife could not change the place of residence or to look for a job without the permission of her husband. This situation was very tiring, when a husband had emigrated or had gone missing. At that time, a separation and passport were given

${ }^{25}$ The application of the peasant Šumaniene to the Consistory of the Žemaitijan Catholics bishopric. 1901, LVIA, f. 669, ap. 4, b. 3743, 1. 1.

${ }^{26}$ Ibid.

${ }^{27}$ Data about separations of Catholics selected from LVIA, f. 669, ap. 4.

${ }^{28}$ Zakony..., 165 . 
to a wife only if the Church Court decreed that a husband had been found neither dead nor alive in the whole Empire. These proceedings continued for several years and, in the eyes of the law, the change of a woman's place of residence was regarded as illegal. For example, Elžbieta Rautmaniené had lived with her husband for 10 years. In 1895 she applied to the Court for a separation. The Court rejected the application. In 1904 she applied the second time and wrote: "Eight years passed since my first application and I have not achieved a positive outcome of the case and could not receive permission to live separately, without which I could hardly provide for myself (...), because, as a tradeswoman, I need to travel to different towns to purchase goods". Only in 1908, after 13 years, the husband of Rautmaniené was acknowledged neither alive nor dead. After this the Church Court conceded the separation for Rautmaniene and the civil authorities handed her the passport ${ }^{29}$.

The Canon Law strictly prohibited the voluntary separation of a married couple ${ }^{30}$. A wife who illegally lived separately from her husband always ran a risk. For example, the peasant Lipskiene who had been deserted by her husband 12 years before and brought up 3 children alone applied in 1898 to the Court, asking for a separation because her husband required the police of Liepaja (Latvia) to deport her, his wife and children to him. The Court had been investigating Lipskiene's case for 13 years and in 1913 conceded at last the separation and acknowledged her right to her own passport ${ }^{31}$.

The Church Court could ask the police for help to force spouses to live together, if the verdict of their case were not in their favour. For example, the noblewoman Ivanauskiene was forced by the Court to return to her husband, although she had a new family and was pregnant ${ }^{32}$.

Neither the course nor the outcome of nullification or separation cases depended on the couples themselves. It was absolutely in the hands of the Church Court, whose main task was to discover those guilty of leading a deviant domestic life and to punish them, not taking into consideration whether the punishment would help to solve problems of the other party. Often during the investigation, plaintiffs themselves could be declared to be a guilty party and in this case a separation or annulment of the marriage become impossible. Even an annulment did not give an opportunity for the other wedding. The Church Court decision could ban a new marriage or specify its conditions. So the practice of the Žemaitijan Church Court reveals that the Catholic population had no chance to adjust their family relations by divorces. Separations, which were given more often, could not solve their problems in their essence.

\footnotetext{
${ }^{29}$ The Rautmanienè divorce case, 1895 , LVIA, f. 669 , ap. 4, b. $2970,1.7$.

${ }^{30}$ Zakony..., 164.

${ }^{31}$ The Lipskienè divorce case (peasant), 1898, LVIA, f. 669, ap. 4, b. 3399, 1. 1.

${ }^{32}$ The Ivanauskienè divorce case, 1870 , ibid., b. 1824, 1.1.
} 


\section{Alternatives to legal divorces}

The prerogative of Church and Civil Courts to divorce spouses or to force them to live together against their will, limited the private life of the Catholics and simultaneously settled the alternatives of solvability of the conjugal relations. As I have mentioned, there were several of them in the society: a change of religion, emigration and atypical families, i.e. "compulsory family" - when the mutual life continued in an actually disintegrated family, and "illegal" - family without legal integration.

To change religion, evidently, was an extreme measure for those seeking a divorce. In the cases I have analyzed, sometimes would-be divorcees converted to Protestantism. In such cases, investigation by the Žemaitijan Consistory was stopped. It is difficult to say what percentage of Lithuanians changed their faith and emigrated because of family problems, rather than political circumstances, or in a search of better life. However, clergy received letters posing a rhetorical question: "Have I, in order only to gain a passport, to change my religion and convert to Orthodoxy, as lawyers have advised? ${ }^{33}$. In periodicals of the Lithuanians Americans it was possible to read advertisements concerned with ascertaining the whereabouts of spouses who ran away from Lithuania.

In the history of culture it is problematical to trace a distinct border between the "compulsory" and so-called "normal" family. Lithuanian literature represents the picture of the traditional family. However, was the family of Katre and Jonas in Žemaite's Marti (Daughter-in-law) a normal or a compulsory one? Maybe both types? An attempt to categorize and identify Lithuanian family is not easy. In this case, I have tried to direct attention to the fact that in Lithuanian culture through the objective social conditions there appeared several models of the family and relations of women and men in it.

Cohabitation in an actually disintegrated family was most common type of the non-traditional family. Compulsory marriage ties, and the failure to change them for a legal alternative, restricted freedom of behaviour. Beating a wife with tied hands and legs became an unremarkable event. Perhaps for this reason while telling the Court about the conjugal life men as well as women inserted the facts about the suffered violation and abasement as the common thing among the other peripetia of their life - poverty or toil ${ }^{34}$. Refined cynicism was rather popular among richer noblemen and landlords. Teodoras Silvestravičius addressed his wife in such a words: "Darling lady of my life, my darling Deity. I could hardly find words to praise and honour you and I would like to express triumph that you are not here anymore. I would pay 10 more years of my life in order to separate with

${ }^{33}$ The Korvin-Kuliešius divorce case (nobleman), 1902, ibid., b. 3856, 1. 100.

${ }^{34}$ The Petreikis divorce case (peasant), 1905, ibid., b. 3242, 1. 16. 
you forever (...). It occurs that many men marry a debaucher, but after some time they try to confess their sins (...). You have nothing more but to find yourself in brothel and to earn there 15 kopecks a day daily $^{35}$. Having no opportunity to divorce, and forced to live together, spouses not only threatened each other (husbands to torture wives to the death, wives to poison their husbands) but they kept their promises too. Of course, such extreme behaviour was not very frequent, nevertheless there is doubt that compulsory relations created a certain atmosphere in the family.

Concrete examples of the "illegal families" are recorded in divorce cases. There are the applications of Lithuanians who lived in Russia and asked to legalize their new, unofficial marriages, nullifying the previous ones, applications of priests requiring the abolishment of illegal unions. These cases could be characterised as unsuccessful attempts to legalise illegal families. However, the majority of examples of illegal families could be found in other cases investigated in the Church Court. The latter have an individual title: "Cases brought on the grounds of lewd life". In other words, there were cohabiting families, which did not legalise their marriage in Church for objective reasons: the previous marriage or separation had not been abolished in a legal way, thus it did not give an opportunity to make a new family. The priests or former consorts acted as plaintiffs in the cases of lewd life. These cases were not categorised among the divorce cases, because the plaintiffs did not ask for a divorce or separation. Their aim was to punish the former spouse with the help of the Church and police, to break up a new family and to return a spouse to the old one. 1973 cases of lewdness were registered in the Zemaitijan Consistory between 1863 and $1904^{36}$. This figure is 15 times higher the number of the official divorces during the same period. The relatively high number of "illegal families" and a low number of the official divorces show the real needs for divorce and the social means for obtaining separations. It would be important to state that divorce and lewd life cases record only those "illegal families" that fell within the Church Court's range of vision. The real number of such unions was probably higher.

Cases which defined by the Church Court as "due to lewd life" sound rather ambiguous, in comparison with the texts themselves. Texts show illegal, but stable, and often permanent family relations. For example, the peasant Ona Vancevičienè in her application to the Consistory wrote that her husband, Kazimieras, had led a depraved life with a married woman, Paulina Burneikienè, for 13 years and had 6 children with her. Her husband, Burneika, indulged in lust with other woman too and had produced 4 children. The plaintiff asked that Vancevičius return to the previous family ${ }^{37}$. Decisions of

${ }^{35}$ The Silvestravičius divorce case (nobleman), 1877, ibid., b. 1489, 1. 7.

${ }^{36}$ Data about "The cases due to lewd life" (1863-1904) selected from: ibid. I. 1 .

${ }^{37}$ The application of Vancevičiene to the Žemaitijan Consistory, 1892, ibid., b. 2511, 
the Church Court required the separation of the "illegal family" of the gentry family of Jonas and Elžbieta Mikuckis, who had lived together for 5 years before the trial and had a child ${ }^{38}$; the family of the noblewoman, Karolina Tamašauskienè, and Kazimieras Gečevskis, who had lived together for 27 years and produced 7 children $^{39}$. The surnames of these women and men are different and their children were registered as illegitimate because there was no chance to legalize an "illegal family". In such situations, even the death of a former spouse did not give an opportunity for a new marriage. The Canon Law prohibited the marriage of former or existing bedfellows.

If, from the point of view of the Catholic Church and Russian Civil Law, the "illegal family" was a marginal phenomenon and could be prosecuted, it was apparently regarded by society as an unnatural but inescapable reality. There is no evidence to suppose that common people and certain priests had an especially negative standpoint toward the "illegal family". Noblemen as well as peasants characterized the "illegal family" by the same notions as the legal one. During divorce cases the absolute majority of plaintiffs and defendants in legal terms defined their illegal bedfellows as husbands and wives and their illegal unions as marriages. In their applications to the Church Court asking for a separation or annulment of the previous, legally valid union plaintiffs stated that they had remarried ${ }^{40}$, although understanding perfectly that the sacrament of marriage had not been received in the Church and that their union was illegal. We could ascribe the same categories of thinking to priests too. A priest from Šilale presenting material about the lewd life of his parishioners to the Consistory wrote: "I have honour to inform the Consistory of illegal life of the nobleman Herbertas Gedgaudas, who took a married woman, a peasant named Domicèle Daubarienè, to wife" ${ }^{\text {"41 }}$. The term "due to lewd life" in the jurisdiction of the Church means that the mentioned marriage was not legalized in the Church, but the priest characterizes this couple as married. It does not seem that such ambiguity reveals anything about some uncomfortable feeling of the part of the priest.

The rate of the cases "due to lewd life" indicates the growth of the illegal families till the very beginning of the 20th century ${ }^{42}$.

On the other hand, this was a natural phenomenon because the amount of divorces and secondary marriages in Europe as well as in America increased constantly. However, there was an essential difference in Lithuania - divorce and second marriage there were illegal. The scale of illegal divorces was especially large in Lithuania between the World Wars, when marriage had been regulated in independent

\footnotetext{
${ }^{38}$ Due to lewd life of the nobleman Mikuckis, 1883, ibid., b. 2366, 1. 1.

${ }^{39}$ The Tamašauskas divorce case (nobleman), 1895, ibid., b. 2983, 1. 1.

${ }^{40}$ The divorce of a nobleman (surname is illegible), 1870, ibid., b. 3126, 1. 1.

${ }^{41}$ Due to Gedgaudas' lewd life (nobleman), 1897, ibid., b. 3367, 1. 1.

${ }^{42}$ Data selected from: ibid.
} 
Lithuania by the same slightly modified Civil Law as in Tsarist Russia. More often, while judging the question of a divorce and a new marriage it was impossible not to offend the standards of the Church or to change the faith in order to marry for a second time, e.g. in Protestant Klaipeda. According to various authors, there were between 8000 and 30.000 divorced persons of the Catholic faith who had done this without the permission of the Church Court ${ }^{43}$. They could create a new family relations only in an illegal way, i.e. an "illegal family".

\section{Illegitimate children}

If the origin of the "illegal family" was decided by the judicial norms, which regulated the marriage, so it settled the other phenomenon in the history of culture - the statistics of illegitimate children of the Catholic population.

On the one hand, it was caused by the consequence of the "illegal family", on the other, it was one more argument proving its existence. Between 1863 and 1904, in the Kaunas gubernia, the average of the Catholic illegitimate births reached $1944^{44}$. At first sight this number does not arise curiosity and the first idea that comes to mind is to liken these babies to children portrayed in literature, such as Magdelè by Petkevičaitè-Bitè and Veronika by Vienuolis. For pregnant girls this figure is significant in comparison with statistics of births in the other confessions of the Kaunas gubernia. Protestants and Jews registered an average 13 and 31 illegitimate babies per year respectively ${ }^{45}$. Thus, per 1000 babies born to Catholics, 5,6 were illegitimate, per 1000 Jewish births the figure was 0,6; among the Protestants - 4. Linking the birth of the illegitimate children only with single mother it would be possible to speak about the rather early spreading of a pre-marital relations in Lithuania, even in comparison with Western Europe. At the same time, it shows the different conception of morality expressed by the Catholics and believers of the other confessions. However, neither Lithuanian literature nor the other sources of the history of culture reveal any signs of an early sexual revolution in Lithuanian society in the second half of the 19th century. By no means do we meet with the particularly hostile or even brutal standpoint of majority towards pre-marital relations. A few months old Magdelè's son is left alone near the well on the cold night, pregnant Veronika drowns herself and the door of her house is smeared with tar as a sign of total intolerance. We find a similar reaction to divorce cases. A husband whose wife had lost her virginity before marriage had a legal right to apply the Consistory for a separation. The morality of a bride was an extraordinary important question during investigation of divorce cases in the Court. The applications of wives to divorce usually

${ }^{43} \mathrm{~L}$. Purènienè, Jungtuvès ir išsiskyrimai, Kaunas, 1936, 119; J. Sideravičius, Teisinis santuokos reguliavimas buržuazinèje Lietuvoje, LMADA, 2(75), 1981, 43.

${ }^{44}$ Data about the illegitimate Catholic births: Pamiatnaia knizhka Kovenskoj gubernii.

${ }^{45}$ Ibid. 
begin with the words: "I, the plaintiff, being a virgin, was legally married $(\ldots)^{\prime 46}$. Thus in the second half of the 19th century, the point of view of the Catholic Church as well as of Lithuanian society towards single mothers was uniformly negative and could not stimulate the birth of the illegitimate babies, number of which considerably exceeded the data of the same character among the other confessions. Maybe the phenomenon of illegitimate births could be linked with the fact that different confessions had different legal standards concerning marriage and divorce. Jews acknowledged only one form of divorce - entirely legal divorce ${ }^{47}$. The latter did not require a complicated confused investigation of a case and depended absolutely on the personal will of spouses. After a husband in the presence of a rabbi and witnesses gave the properly prepared act of divorce to a wife saying: "Now you are divorced from me and free to the other men"48, the formalities of Jewish divorce were ended. From that moment a wife as well as a husband could legally re-marry ${ }^{49}$. It does not mean that divorces of the Jews were ill thought out, because the property relations of a dissolved family were strictly regulated ${ }^{50}$. The Jews having an option in private life could consciously control their relationships. It is natural that among the Jews the official divorces were a more frequent phenomenon. In 1897 , according to the census, there were 434 divorced Jews, 846 divorced Lithuanians and Poles in the Kaunas gubernia ${ }^{51}$. Thus per 1000 Jews of 29-69 age, 4,5 were officially divorced. Per 1000 Lithuanians and Poles of the same age group this number was $1,4^{52}$. The latter number could be lower, because among Lithuanian-and Polish-speaking people the Evangelists were not distinguished as a separate group.

The phenomenon of the illegitimate children is interesting and worth a separate discussion. People who had this social status met with the certain discrimination provided by the civil authorities and the Church Law regulated the standards of marriage; they forbade the naming of illegitimate children after their father, and did not permit them to inherit from their mother's or even more their fathers' relatives and also forbade them to become a priest. However, as I have mentioned, this phenomenon has interested me as much as a proof that in Lithuania the traditional and atypical family existed side by side. The premises of the formation of the atypical family could be found in the standards of the Church and Russian Civil Laws, which settled the norms of private life for the most part. Certainly the "illegal" and "compulsory" families did not constitute a majority in

${ }^{40}$ The divorce case of the Radvilauskas family, 1896, LVIA, f. 669 , ap. 4, b. 3130, 1. 1.

${ }^{47}$ Zakony..., 280.

${ }^{48}$ Ibid., 289.

${ }^{49}$ Ibid., 285.

${ }^{50}$ Ibid., 302.

${ }^{51}$ Pervaia vseobshschaia perepis' naseleniia Rossiiskoj imperii, 1897 g., Kovenskaia guberniia, SPb, 1904, 128.

${ }^{52}$ Ibid. 
Lithuanian society in the second half of the 19th and the beginning of the 20th centuries. In these families as well as in the traditional ones there spread certain models of family relations which decided the selfexpression of women and men in the family and out of it - in the society. So it is sensible to try to categorise not only the traditional but also the atypical, marginal families.

\section{Conclusions}

1. Legal questions of divorce among the Catholic population were governed by the Russian Civil Law, which provided the religious way of the divorce. Referring to the analysis of the Church Court's practice, it is possible to draw the conclusion that the Lithuanians had no opportunity to regulate their marriages by divorce.

2. The prerogative of the Church and Civil Courts to divorce spouses or to force them to live together against their will restricted the private life of Lithuanians and encouraged alternative ways of solving problems of family relations. There were several such solutions: changing faith, emigration and atypical families. Atypical families were divided into: a) "compulsory families", - when the marital life was led in actually disintegrated families and b) "illegal families", i.e. families living without legal registration.

3. The social need for divorce was much greater and did not correspond with the official statistics. The illegal solution of the family problems indicates some reservation on a certain part of society towards the Catholic Church and Russian Civil Law.

4. Illegal ways of regulating marriage (the "illegal family") prompted the other phenomenon of the history of culture - statistics of the Catholic illegitimate births. 